\title{
Radiation protection and cytotoxicity effects of different concentrations of cerium oxide nanoparticles in aqueous solution combined with sodium dodecyl sulphate in Vero cells irradiated with 18 MV beams
}

\author{
Y. Moghimi' ${ }^{1,2}$, A. Banaei3, M. Majdaeen4*, H. Zamani', \\ R. Abedi-Firouzjah ${ }^{1,5^{*}}$ \\ ${ }^{1}$ Department of Medical Physics, Faculty of Medicine, Shahid Sadoughi University of Medical Sciences, Yazd, Iran \\ ${ }^{2}$ Department of Radiology, Faculty of Paramedical Sciences, AJA University of Medical Sciences, Tehran, Iran \\ ${ }^{3}$ Department of Medical Physics, Faculty of Medical Sciences, Tarbiat Modares University, Tehran, Iran \\ ${ }^{4}$ Department of Radiotherapy and Oncology, Razi Hospital, Rasht, Iran. \\ ${ }^{5}$ Cellular and Molecular Research Center, Yasuj University of Medical Sciences, Yasuj, Iran
}

\section{- Original article}

*Corresponding authors:
Mehrsa Majdaeen, Ph.D.,
E-mail:
Mehrsa.majdaeen@yahoo.com,
Razzagh Abedi-Firouzjah, MD.,
E-mail:
$\quad$ razzaghabedi@gmail.com
Revised: December 2020
Accepted: January 2021
Int. J. Radiat. Res., October 2021;
19(4): 913-920
DOI: 10.29242/ijrr.19.4.913

\begin{abstract}
Background: This study aimed to assess and compare the radioprotective and cytotoxic effects of various concentrations of cerium oxide nanoparticles (CONPs) in aqueous solution combined with sodium dodecyl sulphate (SDS) against high energy X-ray beams in Vero cells. Materials and Methods: The scanner electron microscopy (SEM) method was used to analyze the properties of CONPs. The cells were incubated with different concentrations of CONPs in aqueous solution combined with SDS. The non-toxic CONPs concentrations in Vero normal cells were determined using MTT assay. The cell's uptake was measured by an UV/VIS absorption spectrophotometry. The cells were irradiated with different doses of $18 \mathrm{MV}$ photon (1, 2, and $3 \mathrm{~Gy})$, and their viabilities at various concentrations were measured to evaluate the radiation protection effects of CONPs. Results: The CONPs concentrations lower than $600 \mu \mathrm{g} / \mathrm{ml}$ were referred as non-toxic effects regarding MTT results. The $600 \mu \mathrm{g} / \mathrm{ml}$ was regarded as the highest radioprotection effect among the non-toxic concentrations ( $P$-value $<0.05)$. The average percentage of cell viability improvement was estimated as $17,23.61$, and $27.21 \%$ for 1,2 , and $3 \mathrm{~Gy}$ doses, respectively, compared to the control group (with no CONPs). Pearson's correlation coefficients between the CONPs concentration and cell viability were obtained as $0.96,0.99$, and 0.99 for 1,2 , and 3 Gy doses, respectively; showing that the increased concentration leads to an increase in higher radioprotection. Conclusion: The $600 \mu \mathrm{g} / \mathrm{ml}$ of CONPs aqueous solution combined with SDS, as a stable non-toxic concentration, has the highest radiation protection effect when exposed to high-energy photon beams. So, this concentration can be considered as an appropriate candidate of radioprotection for further research.
\end{abstract}

Keywords: Cerium oxide nanoparticles, sodium dodecyl sulphate, radiation protection, high photon energy, MTT test.

\section{INTRODUCTION}

Ionization radiation from medical X-ray systems is one of the main hazard factors that can induce cell damage (1-3). Ionization radiations can have biological effects especially on protein structures, RNA, and DNA, and cause the single or double-stranded chromosome 
breaks (4-6). They create water radiolysis and free radicals in the intercellular environment. Subsequently, free radicals react with surrounding molecules and lead to dysfunction, and even death (7-10).

There are some radiation protection agents which reduce the damage of free radicals (11-13). The choice of agent type could play a significant role in reducing radiation toxicity and its side effects (1). Radiation protectors have different mechanisms like antioxidant effects, scavenging free radicals, regulating cell cycle, and anti-inflammatory effects which lead to a reduction in apoptotic cell death following the ionization radiation $(14,15)$.

Cerium oxide nanoparticles (CONPs) have recently become well known for their radioprotective properties. The most important unique feature of CONPs is the easy switch between $\mathrm{Ce}(3+)$ and $\mathrm{Ce}(4+)$ modes that effectively eliminates free reactive oxygen species $(1,16)$. This biological property identifies CONPs as an effective radio-protector due to the self-regeneration cycle after interacting with free radicals compared to the other radioprotectors like vitamin $\mathrm{E}$ and melatonin (16-19).

Due to the complex mechanisms of nanoparticles in different concentrations which protect normal cells from radiation toxicities, the appropriate concentration must be chosen for every radioprotective agent. To this end, the best concentration of CONPs in in-vivo/vitro conditions should have the lowest cytotoxicity besides the high radioprotective effect (20).

The protection of the radiosensitive organs during the irradiation process is essential. Kidney is one of the sensitive organs regarding the ICRP reported weighting factor (which is equal to 0.12 ) (21). Vero cells are a lineage of cells which is isolated from kidney epithelial cells extracted from an African green monkey. In this regard, this cell type has been chosen in the current work.

There are several surfactants which can improve the nanoparticles' distributions, chemical properties, and also reduce the surface tension (22). Three types of surfactants, namely, cationic, anionic, and non-ionic, are used in the synthesis of nanoparticles and they prevent agglomeration of particles and thereby control the distribution and size of the nanoparticles (23). One of the main anionic surfactants is sodium dodecyl sulphate (SDS) that helps the CONPs to have homogenous and stable distribution, as well as dissolving properties. In this condition, normal cells attaching at the bottom of the cell container will not be covered with a layer of nanoparticles, therefore, we expect that the cell viability will be improved in the presence of surfactant agent. The radioprotective effect of adding a surfactant agent to CONPs in an in-vitro condition has not been reported in previous investigations.

Investigating the concentration of CONPs can have a remarkable impact on the cytotoxicity and radioprotection effects. Thus, in the current work, the radiation protection effect of different non-toxic concentrations of CONPs aqueous solution combined with SDS was quantized to obtain the appropriate concentration of CONPs on the Vero cells. Based on our knowledge, the present study is the first research evaluating the radiation protection effect of CONPs combined with SDS surfactant on Vero cell lines at different concentrations and radiation doses of high energy photon beams.

\section{MATERIALS AND METHODS}

\section{Characterization and preparation of CONPs}

This work was carried out following National Research Ethics Board approval with the registration number of "IR.SSU.MEDICINE.REC.1395.297".

In the present experimental study, CONPs $\left(\mathrm{CeO}_{2}\right.$, nanoceria) were purchased from US Research Nanomaterials, Inc (Houston, USA). The SDS surfactant was obtained from Sigma-Aldrich (St Louis, USA). Images of the nanoparticles were recorded using a scanning electron microscopy (SEM, Phenom, Phenom Prox, Netherlands) method with a magnification of 20000x, to obtain the shape and dimension of CONPs using SEM computer image analyzing software (ProSuite, Phenom, Netherlands). The purchased $\mathrm{CeO}_{2}$ nanoparticles powder was

Int. J. Radiat. Res., Vol. 19 No. 4, October 2021 
dissolved in pure water at different concentrations (100 to $1000 \mu \mathrm{g} / \mathrm{ml}$, with 100 $\mu \mathrm{g} / \mathrm{ml}$ steps), using 0.045 weighting percentage SDS. The surfactant was added along with a cerium nitrate hexahydrate solution.

A spectrophotometer (UV/VIS Double Beam Spectrometer, Lambda365, PerkinElmer, USA) was used for recording the maximum wavelength of absorption spectra of CONPs aqueous solution and the standard curve was plotted (XLABEL: Concentration, YLABEL: Absorbance) for measuring nanoparticle concentration. The prepared CONPs suspensions were conserved for $24 \mathrm{~h}$ and their UV/VIS absorption was recorded to find the concentration value.

The prepared CONPs solutions at different concentrations were mixed using Vortex (VIBROFIX VF1, IKA-WERK, Germany) mixer for 2-3 minutes. Then, the CONPs suspensions were sonicated for 7 hours with $40 \mathrm{kHz}$ ultrasound waves in an ultrasonic cleaning unit (ELMA D-78224 SINGEN/HTW, Germany) with $340_{\text {watt }}$ power. It has been proven that the sonication of CONPs aqueous solution combined with SDS surfactant will result in the increase of suspension stability over time (24).

\section{Cell culture}

The Vero epithelial cells were obtained from the National Center of Genetic and Biological Reservoirs (Tehran, Iran). They were cultured in DMEM (Dulbecco's Modified Eagle Medium, MERCK, Germany) containing 10\% FBS (Fetal Bovine Cerium, MERCK, Germany) along with penicillin antibiotics $(100 \mathrm{IU} / \mathrm{ml})$ and streptomycin $(100 \mu \mathrm{g} / \mathrm{ml})$ and stored in an incubator with $5 \% \mathrm{CO}_{2}$ at $37{ }^{\circ} \mathrm{C}$. To trypsinize the cells, $0.25 \%$ trypsin and $0.03 \%$ EDTA solution were used in phosphate salt buffer $(\mathrm{pH}=7.2)$.

\section{Cellular uptake}

The cell staining and cellular uptake of CONPs were measured based on the method described in a previous study by Popov et al. (18). Approximately $2 \times 10^{5}$ cells were cultured in 90-well plates and were incubated for 24 hours. The cells were treated with non-toxic Int. J. Radiat. Res., Vol. 19 No. 4, October 2021 concentrations of CONPs suspensions combined with SDS in filtered plans. Trypsin was used to separate the cells from the wells. Then, they were mixed to allow the lysing cells and release the absorbed nanoparticles by the cells. The UV/ VIS absorbed spectrophotometry was used to obtain the concentration of CONPs in each suspension. In this method, the absorbance in a certain wavelength determines the concentration using an obtained curve for relationship between absorbance and concentration.

\section{MTT test}

MTT assay (3-[4,5-dimethylthiazol-2-yl]-2, 5-diphenyltetrazolium bromide) was used to determine the effect of toxicity and also to investigate the growth and proliferation of cells treated with CONPs after irradiation. This method is based on the breakdown of tetrazolium salt by the mitochondrial enzyme dehydrogenase succinate from the affected cells (25). To perform this test, the Vero cells with a density of 20,000 cells/well were cultured in each of the 96-well plates. The cells were treated with concentrations of 0 (control group), 100, $200,300,400,500,600,600,700,800,900$, and $1000 \mu \mathrm{g} / \mathrm{ml}$ of CONPs for 24 hours. After this time period, the medium of the wells was emptied and MTT with a concentration of $5 \mathrm{mg} /$ $\mathrm{ml}$ of $20 \mu \mathrm{l}$ was added to each well and kept for 4 hours in $5 \% \mathrm{CO}_{2}$ at $37{ }^{\circ} \mathrm{C}$. Then, the cells were washed with PBS buffer and 100 dimethyl sulphoxide (Cinagen ${ }^{\circledR}$, Iran) solution was added to each well for solving formazan crystals and then vigorously shaken for $10 \mathrm{~min}$ in darkness. The optical absorption of each well was read by an Elisa Biotech (Model: Box998) device at a reference wavelength of $570 \mathrm{~nm}$ (triplicate). The IC90 (a concentration the CONPs that results in $10 \%$ of cell death) value was measured by evaluating cell viability at various concentrations to find non-toxic ones.

\section{$X$-ray irradiation}

After determining the non-toxic CONPs concentrations, the CONPs suspensions were given to the cells and the cells were irradiated with 18 MV photon beams from Clinac-2100 
linear accelerator (Varian Medical Systems, Palo Alto, CA) of 1, 2, and 3 Gy doses with a dose rate of $300 \mathrm{cGy} / \mathrm{min}$. The doses were measured at the reference depth in a water phantom using a calibrated ion chamber (Farmer, PTW, Germany). Finally, the mean cell viability percentage of the irradiated groups was determined after a $24 \mathrm{~h}$ incubation by MTT test.

\section{Statistical analysis}

One-way ANOVA and Tukey tests were performed by SPSS 16 (IBM, USA) to compare the results between different concentrations. Furthermore, Pearson's correlations were calculated between the concentration of CNOPs and cell viability at different radiation doses. The level of statistical significance was set at $\mathrm{P}<0.05$. It must be mentioned that the Kolmogorov-Smirnov statistical test was used to assess the normality of data distributions with the significance level of $95 \%$ before the other statistical analyses.

\section{RESULTS}

\section{Characterization of CONPs}

Figure 1 presents an image taken by the SEM method with a 5000x magnification, showing the size distribution of CONPs. The CONPs have an almost spherical structure, although in some places they have accumulated and agglomerated, which can be distributed by sonication. The diameter measured of CONPs used in this study was $50 \mathrm{~nm}$.

In figure 2, the UV/VIS absorption spectrum of CONPs dissolved in deionized water is shown. The maximum absorption value was 1.5394 a.u occurring at $318 \mathrm{~nm}$. The wavelength of $318 \mathrm{~nm}$ was used for subsequent readings and plotting of the standard curve with the purpose specifying the absorption of CONPs by Vero cells.

\section{Cytotoxicity results}

The Vero cells were treated with 11 different concentrations including 0 (control group), 100, $200,300,400,500,600,700,800,900$, and 1000 $\mu \mathrm{g} / \mathrm{ml}$ for the purpose of investigating the 916
CONPs toxicity. The results of MTT assessment showed that CONPs with stable distribution of up to $600 \mu \mathrm{g} / \mathrm{ml}$ concentration in aqueous solution combined with SDS would not be particularly toxic to the cells (figure 3). The average mortality rate at a concentration of $600 \mu \mathrm{g} / \mathrm{ml}$ was $10.1 \%$. Therefore, CONPs with concentrations $\leq 600 \mu \mathrm{g} / \mathrm{ml}$ were used in order to investigate the radiation protection effect.

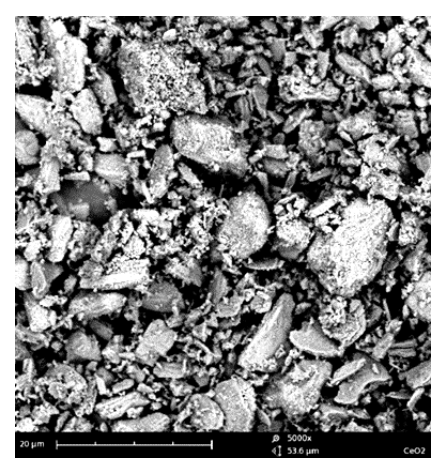

Figure 1. SEM image with 5000x magnification showing the size distribution of cerium oxide nanoparticles purchased from US Research Nanomaterials, Inc (Houston, USA).

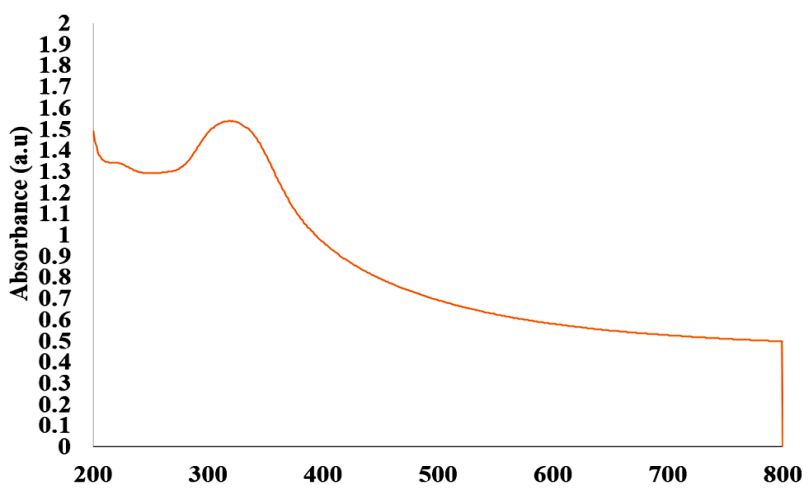

Figure 2. The UV/VIS absorption spectrum of CONPs showing maximum absorption value of 1.5394 a.u at $318 \mathrm{~nm}$.

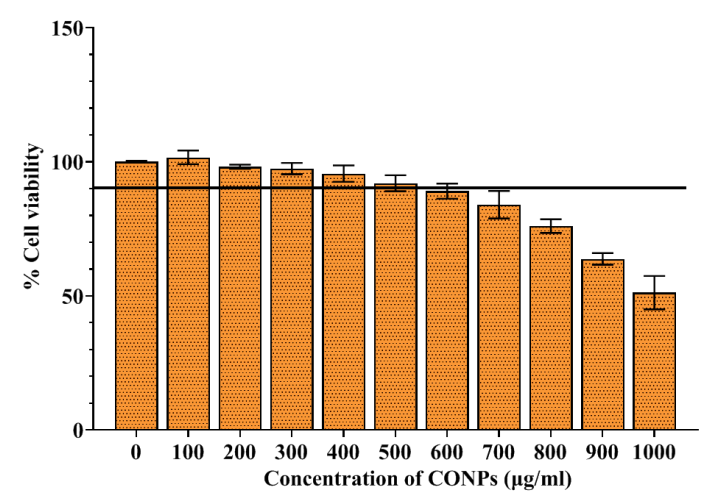

Figure 3. Average percentage of Vero cell viability at different CONPs concentrations obtained from MTT assay for determining the nanoparticles' toxicity. Error bars show standard deviation values. The horizontal line depicts a concentration the CONPs that results in $10 \%$ of cell death.

Int. J. Radiat. Res., Vol. 19 No. 4, October 2021 


\section{Cellular uptake}

The average and standard deviation of cellular uptake values for Vero cells incubated with various concentrations of the non-toxic CONPs concentrations after 24 hours are presented as a curve in figure 4. A linear trend line was fitted to the data and a strong linear correlation was observed between the cellular uptake and CONPs concentration $\left(R^{2}=0.98\right)$.

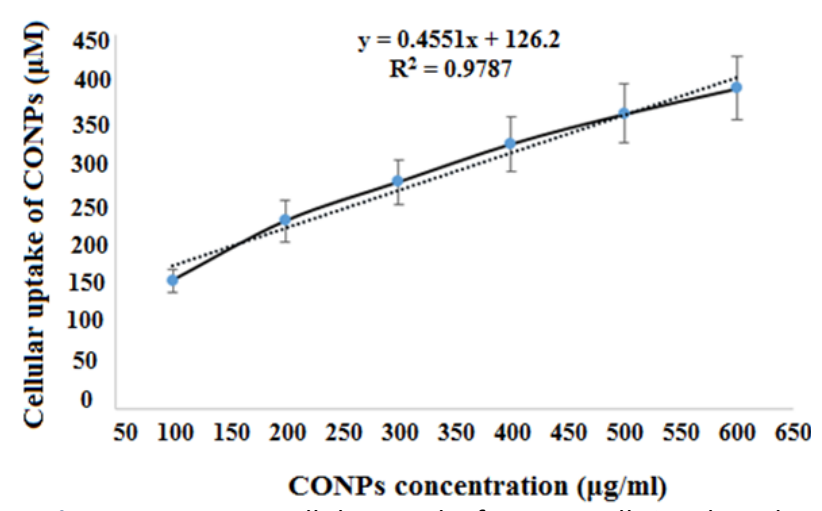

Figure 4. Average cellular uptake for Vero cells incubated with various concentrations of the non-toxic CONPs after 24 hours. The dashed line shows the linear trend line (with the equation and $\mathrm{R} 2$ value represented in the curve) fitted to the cellular uptake with the data relating to various concentrations. Error bars show the standard deviation values.

\section{Radioprotection effects of CONPS}

The average cell viability (\%) increased with the increment of CONPs concentration when the cells were irradiated with 1 Gy dose (figure 5.a), and it was found that only $17 \%$ of cells were killed by high energy X-ray irradiation in the presence of $600 \mu \mathrm{g} / \mathrm{ml}$ of CONPs, while this value was $47 \%$ in the control group.

In other irradiated groups with 2 Gy dose, a concentration of $600 \mu \mathrm{g} / \mathrm{ml}$ of CONPs led to the retention of $71.4 \%$ of cells against the $47.43 \%$ viability in the irradiation only group (figure 5.b). Therefore, the concentration of $600 \mu \mathrm{g} / \mathrm{ml}$ increased the cell viability by $23.61 \%$ at 2 Gy dose.

The findings for 3Gy irradiated groups (figure 5.c) showed that the treated cells with the concentration of $600 \mu \mathrm{g} / \mathrm{ml}$ CONPs compared to the other concentrations of 0,100 , $200,300,400$, and $500 \mu \mathrm{g} / \mathrm{ml}$, had a higher cell viability by $27.21,28.18,24.21,17.12,13.1$, and $6.29 \%$, respectively.

Int. J. Radiat. Res., Vol. 19 No. 4, October 2021
In all three doses, the differences of cell viability between the $600 \mu \mathrm{g} / \mathrm{ml}$ and other concentration groups were significant $(\mathrm{P}<0.05)$, except in 2 Gy X-ray irradiation groups between 500 and $600 \mu \mathrm{g} / \mathrm{ml}$ concentrations (figure 5.b). In addition, Pearson's correlation coefficients $\left(\mathrm{R}^{2}\right)$ between the CONPs concentration and cell viability were $0.96,0.99$, and 0.99 for 1,2 , and 3 Gy doses, respectively. According to the correlation findings, increasing the concentration causes higher radioprotection.
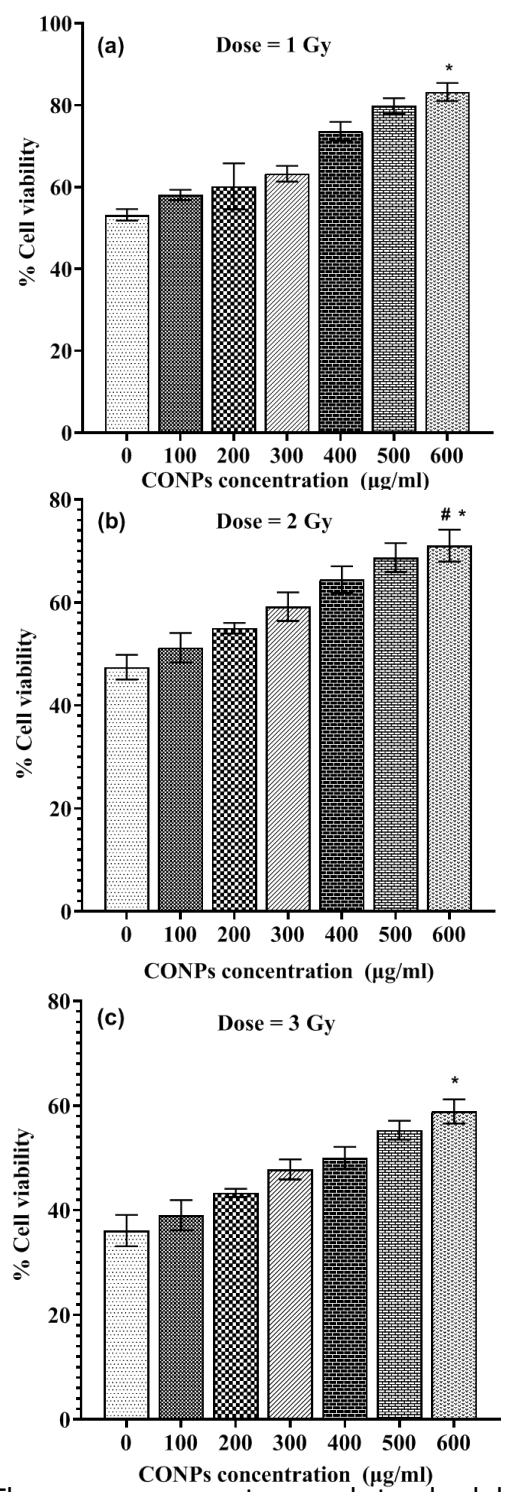

Figure 5. The average percentage and standard deviation (error bars) values of Vero cell viability in the presence of different CONPs concentrations irradiated with $18 \mathrm{MV}$ photon beams at a dose of $1 \mathrm{~Gy}(\mathrm{a}) ; 2 \mathrm{~Gy}(\mathrm{~b})$; and $3 \mathrm{~Gy}$ (c). *Significant difference compared to the other groups (P-value<0.05). "No significant difference compared to the $500 \mu \mathrm{g} / \mathrm{ml}$ concentration. 
Cell viability change in the presence of 600 $\mu \mathrm{g} / \mathrm{ml}$ CONPs against the control group in the three doses

The cell viability percentage at 3 Gy dose was the lowest value in the $600 \mu \mathrm{g} / \mathrm{ml}$ CONPs concentration; nonetheless, the cell viability showed the highest differences with the control group $(27.21 \%)$ compared to other doses (figure 6). These variations for the doses of 1 and 2 Gy were 17 and 23.61\%, respectively. In addition, there were remarkable differences between the $600 \mu \mathrm{g} / \mathrm{ml}$ concentration among 1, 2, and $3 \mathrm{~Gy}$ (P-value<0.01).

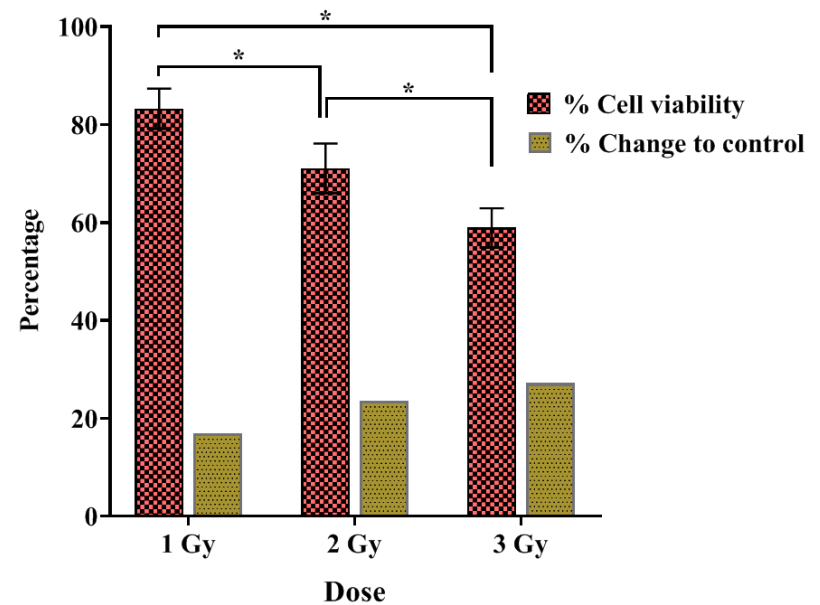

Figure 6 . The average percentage and standard deviation (error bars) values of cell viability and percentage change compared to the control group in the presence of the $600 \mu \mathrm{g} /$ $\mathrm{ml}$ CONPs concentration at 1, 2, and 3 Gy doses. Significant differences were observed in all groups shown with * signs (P-value<0.01).

\section{DISCUSSION}

CONPs have been proven as appropriate radioprotector agents using different radiobiological exams $(1,18,26,27)$. For example, Zal et al. (27) investigated the protective effect of CONPs on human lymphocyte cells against ionization radiation at a dose of $1.5 \mathrm{~Gy}$. They expressed that CONP is able to inhibit apoptosis and necrosis significantly. In another study, Popov et al. (18) reported that CONPs could reduce free radical levels and cytogenetic damage significantly in mice bone marrow cells up to $50 \%$ when they were irradiated with $7 \mathrm{~Gy}$ dose of $200 \mathrm{kV}$ photon beam. In the present work, we investigated the radiation protection effects of various concentrations of CONPs aqueous solution combined with SDS surfactant on Vero normal cell lines of high energy X-rays which have not been assessed in previous studies.

In general, the size of CONPs via hydroxide mediated method without using any surfactant has been reported to be in the range of 18-30.4 $\mathrm{nm}(20,28)$, whereas our results determined that the diameter of the spherical CONPs with SDS surfactant was $50 \mathrm{~nm}$. This discrepancy with the other investigations could be related to the different types of nanoparticle distribution and water environment.

One of the main advantages of using the CONPs as a radioprotector is the selfregenerative properties and the reactivation of active sites to sweep free radicals which can play a significant role in reducing the toxicity effect (29,30). For this reason, even using low concentrations of CONPs can protect healthy cells from irradiation. The structure of CONPs includes $\mathrm{Ce}(3+)$ and $\mathrm{Ce}(4+)$, in which free radicals are swept by the reaction with $\mathrm{Ce}_{3} \mathrm{O}_{2}$, and $\mathrm{CeO}_{2}$ is produced. Due to its regenerative properties, $\mathrm{CeO}_{2}$ changes to $\mathrm{Ce}_{3} \mathrm{O}_{2}$ which is able to sweep the reactive oxygen species. The sweep ability of free radicals by the CONPs (CONPs' biological activity) is determined by the ratio of Ce $(3+)$ to $\mathrm{Ce}(4+)$. The higher this ratio, the higher the sweeping property which depends on the CONPs synthesis method, so $\mathrm{Ce}(3+)$ is considered as an active agent for sweeping free radicals (31-33).

Although CONPs have a lot of benefits in comparison to the other nanoparticles, the half-life of these particles is longer than the other radiation protection compounds such as amifostine (20). This can be an important reason for finding the appropriate stable non-toxic concentration of CONPs for further research on the radioprotective effect of this nanoparticle. Based on the MTT test results, the non-toxic CONP concentrations in the presence of SDS surfactant were found to be less than $600 \mu \mathrm{g} / \mathrm{ml}$. The concentration of $100 \mu \mathrm{g} / \mathrm{ml}$ had the lowest non-toxic effect, and also it had the lowest radiation protection effect compared to the

Int. J. Radiat. Res., Vol. 19 No. 4, October 2021 
higher concentrations. For this reason, the 600 $\mu \mathrm{g} / \mathrm{ml}$ as the highest ionization protection and non-toxic concentration was chosen for this research study. In several studies, concentrations similar to these have been reported as non-toxic concentrations of CONPs, which can vary depending on how the nanoparticles are distributed, the nanoparticle dimensions, the cell line studied, and the cell mortality test $(20,34,35)$.

The cellular uptake of the nanoparticles in Vero cells at various CONPs concentrations in the present study was low compared to the results of previous studies which used the CONPs aqueous solutions without SDS $(1,18,20,27)$. Although the presence of SDS resulted in a decrease of cellular uptake, this surfactant resulted in having a stable CONPs solvent over the relatively long time period (72 hours) (24). This is due to the fact that SDS as a surfactant agent makes suspension from CONPs by giving negative electrical charges to the CONPs surface which distributes homogeneously in the volume of aqueous solution. The role of SDS stability of CONPs has been investigated in a study by Abdi et al. (24). They reported that the stability of CONPs decreased significantly after 24 hours of production without using SDS, and the CONPs settled at the bottom of the cell container. This increases the encounter rate of nanoparticles with the cell layer at the bottom of the container, and also the cellular uptake (24). In addition, they showed that the 0.045 weighting percentage of SDS is the optimal concentration resulting in relatively homogeneous distribution of CONPs.

The use of CONPs as radiation protection in an optimal concentration in laboratories is a challenge. Therefore, for future research, it is suggested that obtaining the best concentration of CONPs should be examined by various tests, cell categories, and also different doses/dose rates of $18 \mathrm{MV} \mathrm{X}$-ray beams. In addition, it is possible to assay the radioprotective effects of CONPs of different sizes combined with different surfactants. Since, in the present study, we only assessed the radioprotective and cytotoxic effects of CONPs (combined with SDS) in Vero cells, it's possible to investigate it in an in-vivo condition with the same concentrations as we investigated.

\section{CONCLUSION}

CONPs aqueous solution combined with SDS as an appropriate surfactant can reduce the risk of specific and random radiation damages against high- energy ionization radiation. In this study, we investigated the non-toxic and radioprotective effects of CONPs (combined with SDS) at different concentrations by MTT test. Ultimately, the $600 \mu \mathrm{g} / \mathrm{ml}$ concentration of CONPs was chosen as the appropriate concentration compared to the others due to the high impact of cell restoration after high energy $\mathrm{X}$-ray irradiation (18 MV).

\section{ACKNOWLEDGMENT}

This article was supported and approved by Shahid Sadoughi University of Medical Sciences (Yazd, Iran) with the registration number of "IR.SSU.MEDICINE.REC.1395.297".

\section{Conflicts of interest: Declared none.}

\section{REFERENCES}

1. Abdi Goushbolagh N, Abedi Firouzjah R, Ebrahimnejad Gorji K, Khosravanipour M, Moradi S, Banaei A, et al. (2018) Estimation of radiation dose-reduction factor for cerium oxide nanoparticles in MRC-5 human lung fibroblastic cells and MCF-7 breast-cancer cells. Artif Cells Nanomedicine Biotechnol, 46(3): S1215-S1225.

2. Ghorbanian Kelachayeh $\mathrm{S}$, Sangtarash $\mathrm{MH}$, Mozdarani H (2020) The effects of melatonin on the frequency of micronuclei induced by ionizing radiation in cancerous and normal cell lines. Int J Radiat Res, 18(1): 57-64.

3. Nadi S, Banaei A, Mozdarani H, Monfared AS, Ataei GR, Abedi-Firouzjah R (2020) Evaluating the radioprotective effect of arbutin on mice exposed to megavoltage X-rays based on hematological parameters and lymphocytes micronucleus assay. Int J Radiat Res, 18(2): 275-282.

4. Hall EJ and Giaccia AJ (2006) Radiobiology for the Radiologist. Lippincott Williams \& Wilkins. Philadelphia.

5. Saghaei H, Mozdarani H, Mahmoudzadeh A (2019) Sperm DNA damage in mice irradiated with various doses of $X$ rays alone or in combination with actinomycin D or bleomycin sulfate: an in-vivo study. Int J Radiat Res, 17(2): 317 
$-323$.

6. Zangeneh M, Nedaei HA, Mozdarani H, Mahmoudzadeh A, Kharrazi S, Salimi M (2019) The role and mechanisms of zinc oxide nanoparticles in the improvement of the radiosensitivity of lung cancer cells in clinically relevant megavoltage radiation energies in-vitro. Nanomedicine J, 6(4): 276-290.

7. Santivasi WL, Xia F (2014) lonizing radiation-induced DNA damage, response, and repair. Antioxid Redox Signal, 21 (2): 251-259.

8. Lainé $\mathrm{M}$, Balan $\mathrm{E}, \mathrm{Allard} \mathrm{T}$, Paineau $\mathrm{E}$, Jeunesse $\mathrm{P}$, Mostafavi $M$, et al. (2017) Reaction mechanisms in swelling clays under ionizing radiation: influence of the water amount and of the nature of the clay mineral. RSC Adv, 7(1): 526534.

9. Alonso-González C, González A, Martínez-Campa C, Gómez -Arozamena J, Cos S (2015) Melatonin sensitizes human breast cancer cells to ionizing radiation by downregulating proteins involved in double-strand DNA break repair. $J$ Pineal Res, 58(2): 189-197.

10. Azimi S, Mozdarani H, Mahmoudzadeh A (2017) Induction of DNA damage, apoptosis and micronuclei in peripheral blood lymphocytes following injection of contrast media in patients with abdominal CT scan. Int J Radiat Res, 15(2): 149-155.

11. Velpula N, Ugrappa S, Kodangal S (2013) A role of radioprotective agents in cancer therapeutics: a review. Int J Basic Clin Pharmacol, 2(6): 677-82.

12. Targhi RG, Banaei A, Saba V (2019) Radioprotective effect of grape seed extract against gamma irradiation in mouse bone marrow cells. J Cancer Res Ther, 15(3): 512.

13. Majdaeen M, Banaei A, Abedi-Firouzjah R, Gorji KE, Ataei $G$, Momeni F, et al. (2020) Investigating the radioprotective effect of sesamol oral consumption against gamma irradiation in mice by micronucleus and alkaline comet assays. Appl Radiat Isot, 159: 109091.

14. Velpula N, Ugrappa S, Kodangal S (2013) A role of radioprotective agents in cancer therapeutics: a review. Int J Basic Clin Pharmacol, 2(6): 677-82.

15. Bonner WM (2003) Low-dose radiation: thresholds, bystander effects, and adaptive responses. Proc Natl Acad Sci, 100(9): 4973-4975.

16. Xu C and Qu X (2014) Cerium oxide nanoparticle: a remarkably versatile rare earth nanomaterial for biological applications. NPG Asia Mater, 6(3): e90-e90.

17. Wang C, Blough E, Dai X, Olajide O, Driscoll H, Leidy JW, et al. (2016) Protective effects of cerium oxide nanoparticles on MC3T3-E1 osteoblastic cells exposed to X-ray irradiation. Cell Physiol Biochem, 38(4): 1510-1519.

18. Popov AL, Zaichkina SI, Popova NR, Rozanova OM, Romanchenko SP, Ivanova OS, et al. (2016) Radioprotective effects of ultra-small citrate-stabilized cerium oxide nanoparticles in-vitro and in-vivo. RSC Adv, 6(108): 106141-49.

19. Amini P, Mirtavoos-Mahyari H, Motevaseli E, Shabeeb D, Musa AE, Cheki M, et al. (2019) Mechanisms for radioprotection by melatonin; can it be used as a radiation countermeasure? Curr Mol Pharmacol, 12(1): 2-11.

20. Goushbolagh NA, Farhood B, Astani A, Nikfarjam A, 920
Kalantari M, Zare MH (2018) Quantitative cytotoxicity, cellular uptake and radioprotection effect of cerium oxide nanoparticles in MRC- 5 normal cells and MCF-7 cancerous cells. BioNano Science, 8(3): 769-777.

21. Streffer C (2007) The ICRP 2007 recommendations. Radiat Prot Dosimetry, 127(1-4): 2-7.

22. Reshma P and Ashwini K (2017) Cerium Oxide Nanoparticles: Synthesis, Characterization and Study of Antimicrobial Activity. J Nanomater Mol Nanotechnol, 4: 1-4.

23. Riccardi CS, Lima RC, Dos Santos ML, Bueno PR, Varela JA, Longo E (2009) Preparation of $\mathrm{CeO} 2$ by a simple microwave-hydrothermal method. Solid State Ion, 180(2-3): 288-291.

24. Abdi GN, Astani A, Zare MH (2018) Optimization of condition for Cerium Oxide Nanoparticles dispersion as radioprotective agent in deionized water. SSU_Journals, 26(9): 784-795.

25. Mosmann T (1983) Rapid colorimetric assay for cellular growth and survival: application to proliferation and cytotoxicity assays. J Immunol Methods, 65(1-2): 55-63.

26. Kargar H, Ghasemi F, Darroudi M (2015) Bioorganic polymer-based synthesis of cerium oxide nanoparticles and their cell viability assays. Ceram Int, 41(1): 1589-1594.

27. Zal Z, Ghasemi A, Azizi S, Asgarian-Omran H, Montazeri A, Hosseinimehr SJ (2018) Radioprotective effect of cerium oxide nanoparticles against genotoxicity induced by ionizing radiation on human lymphocytes. Curr Radiopharm, 11 (2): 109-115.

28. Chelliah M, Rayappan JBB, Krishnan UM (2012) Synthesis and characterization of cerium oxide nanoparticles by hydroxide mediated approach. J Appl Sci, 12(16): 17341737.

29. Pešić $M$, Podolski-Renić $A$, Stojković $S$, Matović $B, Z$ mejkoski D, Kojić V, et al. (2015) Anti-cancer effects of cerium oxide nanoparticles and its intracellular redox activity. Chem Biol Interact, 232: 85-93.

30. Rubio L, Annangi B, Vila L, Hernández A, Marcos R (2016) Antioxidant and anti-genotoxic properties of cerium oxide nanoparticles in a pulmonary-like cell system. Arch Toxicol, 90(2): 269-278.

31. Singh VK, Shafran RL, Jackson III WE, Seed TM, Kumar KS (2006) Induction of cytokines by radioprotective tocopherol analogs. Exp Mol Pathol, 81(1): 55-61.

32. Ouyang Z, Mainali MK, Sinha N, Strack G, Altundal Y, Hao $Y$, et al. (2016) Potential of using cerium oxide nanoparticles for protecting healthy tissue during accelerated partial breast irradiation (APBI). Phys Med, 32(4): 631-635.

33. Baker $\mathrm{CH}$ (2013) Harnessing cerium oxide nanoparticles to protect normal tissue from radiation damage. Trans/ Cancer Res, 2(4): 343-358.

34. Lin W, Huang Y, Zhou X-D, Ma Y (2006) Toxicity of cerium oxide nanoparticles in human lung cancer cells. Int J Toxicol, 25(6): 451-457.

35. García-Alonso J, Rodriguez-Sanchez N, Misra SK, ValsamiJones E, Croteau M-N, Luoma SN, et al. (2014) Toxicity and accumulation of silver nanoparticles during development of the marine polychaete Platynereis dumerilii. Sci Total Environ, 476: 688-695.

Int. J. Radiat. Res., Vol. 19 No. 4, October 2021 